\title{
Extraction methods and availability of phosphorus for soybean in soils from Paraná State, Brazil
}

\section{Métodos de extração e disponibilidade de fósforo para a soja em solos do Paraná}

\author{
Fábio Steiner ${ }^{1 *}$; Maria do Carmo Lana ${ }^{2}$; Tiago Zoz \\ Jucenei Fernando Frandoloso ${ }^{2}$; Rubens Fey ${ }^{2}$
}

\begin{abstract}
In studies on the evaluation of methodologies for the analysis of soil, phosphorus $(\mathrm{P})$ has been the single most studied aspect, due to the complexity of this dynamic element in soil. However, these studies have been limited regarding soil conditions in Paraná. The present study aimed to evaluate the efficiency of the Mehlich-1, Mehlich-3 and ion exchange resin methods in the evaluation of available $\mathrm{P}$ for soybean (Glycine max) in the soils of Paraná State. Twelve soil samples collected from the upper 0-20 cm were planted with soybean for a period of 42 days in the greenhouse. The ability to extract soil $\mathrm{P}$ followed the order of decreasing average amount of extracted P: Mehlich-3 > resin $>$ Mehlich- 1 . The correlation coefficients between the content of $\mathrm{P}$ extracted by Mehlich-1, Mehlich-3 and resin and the amount of $\mathrm{P}$ accumulated in the plants were $0.86,0.90$ and 0.93 , respectively. Mehlich-1, Mehlich-3 and resin showed similar efficiency in the evaluation of $\mathrm{P}$ availability to plants and, under conditions of natural fertility and in soils that had received no application of poorly natural reactive phosphates, can be used to quantify the concentrations of $\mathrm{P}$ in the soils of Paraná State.
\end{abstract}

Key words: Glycine max, availability phosphorus, Mehlich-1, Mehlich-3, ion exchange resin

\section{Resumo}

Nos estudos de avaliação de metodologias de análise de solo, o fósforo (P) tem sido o elemento mais
estudado, em decorrência da complexidade da dinâmica do elemento no solo. No entanto, estes estudos
são escassos para as condições de solos paranaenses. O presente estudo teve como objetivo avaliar a
eficiência dos extratores Mehlich- 1 , Mehlich-3 e resina de troca iônica na avaliação do P disponível
para plantas de soja (Glycine max) em solos do Estado do Paraná. Amostras de doze solos coletadas da
camada de $0-20 \mathrm{~cm}$ de profundidade foram cultivadas com plantas de soja por um período de 42 dias,
em casa de vegetação. A capacidade de extração de P dos solos seguiu a seguinte ordem decrescente
da quantidade média de P extraído: Mehlich-3 $>$ resina $>$ Mehlich-1. Os coeficientes de correlação
entre o teor de P extraído pelo Mehlich- 1 , Mehlich-3 e resina e as quantidades de P acumulada nas
plantas foram, respectivamente, de $0,86,0,90$ e 0,93 . Os extratores Mehlich- 1 , Mehlich-3 e resina de
troca iônica apresentaram eficiência semelhante na avaliação da disponibilidade de P às plantas e, em
condições de fertilidade natural e em solos que não receberam aplicação de fosfatos naturais poucos
reativos, podem ser utilizados para quantificar os teores de P em solos do Estado do Paraná.
Palavras-chave: Glycine max, disponibilidade de fósforo, Mehlich-1, Mehlich-3, resina de troca iônica

${ }^{1}$ Discentes de Pós-Graduação em Agronomia. Dept ${ }^{0}$ de Produção Vegetal. Faculdade de Ciências Agronômicas, FCA. Universidade Estadual Paulista Júlio de Mesquita Filho, UNESP. Botucatu, SP. E-mail: fsteiner@fca.unesp.br; tiagozoz@fca.unesp.br

${ }^{2}$ Profs. do Centro de Ciências Agrárias, Universidade Estadual do Oeste do Paraná, UNIOESTE. Marechal Cândido Rondon, PR.

E-mail: mclana@unioeste.br; juceneiff@hotmail.com; rubensfey@hotmail.com

* Author for corespondence 


\section{Introduction}

The assessment of phosphorus (P) availability in soil for plants has usually been accomplished by the use of chemical extractants and ion exchange resin (FIXEN; GROVE, 1990). These methods aim to quantifying the possible ways of releasing to the soil during cropping and, consequently, absorption by plants. However, in order for a $\mathrm{P}$ extractor to be considered appropriate, it is necessary that the $\mathrm{P}$ content extracted by this method correlates with the amount of $\mathrm{P}$ accumulated by plants (ALVAREZ VENEGAS, 1996).

Several extraction methods have been proposed to determine $\mathrm{P}$ availability for plants. Each method has greater or lesser ease in extracting $\mathrm{P}$ from different soil types, which is why the evaluation of available $\mathrm{P}$ in soils is the subject of much attention. Acid extractors have a great advantage for routine use, especially given the ease of obtaining clear extracts by decantation, thus avoiding the filtering of soil suspensions (RAIJ; FEITOSA; SILVA, 1984) and the low cost of analysis (ROSSI; FAGUNDES, 1998). However, these extractors do not work in the same way in different soil types, with different abilities to dissolve and solubilize $P$ from phosphate compounds (GONZÁLEZ et al., 2000).

In Paraná State, the Mehlich-1 method is used to assess $\mathrm{P}$ availability to plants. However, in less weathered soils and/or with higher $\mathrm{pH}$ and in soils that have received poorly reactive natural phosphates, the Mehlich-1 method generally overestimates the available $\mathrm{P}$, since the method predominantly dissolves $\mathrm{P}$ bound to $\mathrm{Ca}$, which are the most frequent compounds in these soils, and a small proportion of $\mathrm{P}$ bound to $\mathrm{Fe}$ and $\mathrm{Al}$ (MOREIRA; MALAVOLTA, 2001; SILVA; RAIJ, 1999). Moreover, in heavy clayed soils with high buffering capacity, the amount of $\mathrm{P}$ extracted with Mehlich-1 is underestimated as a result of reduced extraction capacity with the increased soil clay content. The decrease in extraction capacity is due to the consumption of the hydrogen $\left(\mathrm{H}^{+}\right)$and sulfate $\left(\mathrm{SO}_{4}^{2-}\right)$ ions of the extractor by functional groups not occupied by $\mathrm{P}$ in inorganic colloids and also by readsorption of $\mathrm{P}$ already dissolved in colloids during extraction (TEDESCO et al., 1995). Thus, extractors with low P-Ca extraction capacity and high extraction capacity in clay soils, such as ion exchange resin and Mehlich-3, should be better suited than Mehlich-1 (SCHLINDWEIN; BORTOLON; GIANELLO, 2011; OLIVEIRA et al., 2000).

Some studies have shown that the Mehlich-1 and Mehlich-3 extractors and ion exchange resin are equally effective in the evaluation of soil P (BORTOLON et al., 2011; BORTOLON; SCHLINDWEIN; GIANELLO, 2009; SANTOS; KLIEMANN, 2005; MOREIRA; MALAVOLTA, 2001). However, Silva and Raij (1999) compared several methods of $\mathrm{P}$ extraction and, based on the coefficient of determination $\left(\mathrm{R}^{2}\right)$ of the regression between $\mathrm{P}$ extracted from soil by resin and $\mathrm{P}$ accumulated in the plant, concluded that the resin method exceeded the other methods. Silva et al. (1999), when evaluating the efficiency of Mehlich-1, Mehlich-3 and resin in soil from Mato Grosso do Sul, also concluded that the resin method, regardless of soil type and $\mathrm{P}$ source used, was more appropriate for estimating the available P in soil. In turn, Moreira et al. (1997) found that Mehlich-1 and resin showed similar efficiency in the evaluation of $\mathrm{P}$ availability to rice plants, and both were superior to Mehlich-3. In other studies, the Mehlich-3 method has occupied a prominent position in relation to Mehlich-1, as it is more appropriate for estimating $\mathrm{P}$ availability to plants (WANG et al. 2004; RING et al., 2004). Contradictory results have indicated the need for more research, in addition to further refinement of the interpretation that best predicts $\mathrm{P}$ availability and plant responses.

In Paraná State, there have been few studies on methods for assessing P availability, thus making it difficult to define the most appropriate method for soil conditions in Paraná. However, it is essential to conduct research relating the amount extracted 
by the different extractants and the amount of $\mathrm{P}$ accumulated by plants using different extractants in soil testing laboratories.

This study aimed to evaluate the efficiency of Mehlich-1, Mehlich-3 and ion exchange resin in the evaluation of available $P$ to soybean plants in soils with different chemical and physical attributes in the State of Paraná.

\section{Material and Methods}

The experiment was carried out in an experimental greenhouse at the Agronomic Experimental Station, Universidade Estadual do Oeste do Paraná (West Paraná State University) in Marechal Candido Rondon, PR, Brazil (latitude: 243' S, longitude: $54^{\circ} 01^{\prime} \mathrm{W}$, altitude: $420 \mathrm{~m}$ ).
Soil samples were collected from the upper 0-20 $\mathrm{cm}$ at twelve sites in Paraná State covering different regions and characteristics (Table 1). Soils were classified according to Embrapa (2006) as well as chemical and granulometric attributes (Table 2) following the methodology of Embrapa (1997). Soil acidity correction was carried out with lime $(\mathrm{CaO}=$ $25 \%, \mathrm{MgO}=12 \%$ and effective calcium carbonate equivalent $=95 \%$ ) and the need for correction was defined according to the saturation method (RAIJ et al., 1997) to increase it to $70 \%$ for clay soils, $50 \%$ for sandy soils and $60 \%$ for medium texture soils. Soils were moistened to reach $80 \%$ water retention capacity and incubated for 25 days. Subsequently, $7.5 \mathrm{dm}^{3}$ subsamples of each soil were transferred to polyethylene pots with a capacity of $8.0 \mathrm{dm}^{3}$.

Table 1. Classification, origin material and sampling sites of soil samples used in the experiment.

\begin{tabular}{|c|c|c|c|c|c|}
\hline \multirow{2}{*}{ Soil $^{(1)}$} & \multirow{2}{*}{ Brazilian classification $^{(1)}$} & \multirow{2}{*}{ Origin material } & \multirow{2}{*}{ Sampling Municipality } & \multicolumn{2}{|c|}{ Geographical coordinates } \\
\hline & & & & Latitude & Longitude \\
\hline LV1 & Latossolo Vermelho & Basalt & $\begin{array}{l}\text { Marechal Cândido } \\
\text { Rondon }\end{array}$ & $24^{\circ} 32^{\prime} 05^{\prime \prime} \mathrm{S}$ & $54^{\circ} 01^{\prime} 02^{\prime \prime} \mathrm{W}$ \\
\hline LV2 & Latossolo Vermelho & Shale & Ponta Grossa & $25^{\circ} 09^{\prime} 07^{\prime \prime} \mathrm{S}$ & $50^{\circ} 09^{\prime} 21^{\prime \prime} \mathrm{W}$ \\
\hline LVA1 & Latossolo Vermelho Amarelo & Caiuá sandstone & Umuarama & $23^{\circ} 48^{\prime} 35^{\prime \prime} \mathrm{S}$ & $53^{\circ} 15^{\prime} 23^{\prime \prime} \mathrm{W}$ \\
\hline LVA2 & Latossolo Vermelho-Amarelo & Furnas sandstone & Ponta Grossa & $25^{\circ} 06^{\prime} 29^{\prime \prime} \mathrm{S}$ & $50^{\circ} 03^{\prime} 09^{\prime \prime} \mathrm{W}$ \\
\hline NV1 & Nitossolo Vermelho & Basalt & $\begin{array}{l}\text { Marechal Cândido } \\
\text { Rondon }\end{array}$ & $24^{\circ} 36^{\prime} 13^{\prime \prime} \mathrm{S}$ & $54^{\circ} 04^{\prime} 06^{\prime \prime} \mathrm{W}$ \\
\hline NV2 & Nitossolo Vermelho & Shale & Ponta Grossa & $25^{\circ} 10^{\prime} 29^{\prime \prime} \mathrm{S}$ & $50^{\circ} 09^{\prime} 07^{\prime \prime} \mathrm{W}$ \\
\hline PVA1 & Argissolo Vermelho-Amarelo & Caiuá sandstone & Umuarama & $23^{\circ} 48^{\prime} 50^{\prime \prime} \mathrm{S}$ & $53^{\circ} 15^{\prime} 11^{\prime \prime} \mathrm{W}$ \\
\hline PVA2 & Argissolo Vermelho-Amarelo & Basalt & Mercedes & $24^{\circ} 24^{\prime} 08^{\prime \prime} \mathrm{S}$ & $54^{\circ} 07^{\prime} 00^{\prime \prime} \mathrm{W}$ \\
\hline $\mathrm{RR}$ & Neossolo Regolítico & Basalt & $\begin{array}{l}\text { Marechal Cândido } \\
\text { Rondon }\end{array}$ & $24^{\circ} 37^{\prime} 55^{\prime \prime} \mathrm{S}$ & $54^{\circ} 04^{\prime} 08^{\prime \prime} \mathrm{W}$ \\
\hline FX & Plintossolo Háplico & Shale & Ponta Grossa & $25^{\circ} 10^{\prime} 30^{\prime \prime} \mathrm{S}$ & $50^{\circ} 09^{\prime} 08^{\prime \prime} \mathrm{W}$ \\
\hline GX & Gleissolo Háplico & Alluvial sediments & $\begin{array}{l}\text { Marechal Cândido } \\
\text { Rondon }\end{array}$ & $24^{\circ} 32^{\prime} 00^{\prime \prime} \mathrm{S}$ & $54^{\circ} 01^{\prime} 25^{\prime \prime} \mathrm{W}$ \\
\hline $\mathrm{CX}$ & Cambissolo Háplico & Furnas sandstone & Ponta Grossa & $25^{\circ} 06^{\prime} 27^{\prime \prime} \mathrm{S}$ & $50^{\circ} 03^{\prime} 08^{\prime \prime} \mathrm{W}$ \\
\hline
\end{tabular}

(1) EMBRAPA (2006).

Source: Elaboration of the authors. 
Table 2. Physical and chemical properties of the 12 soils collected in Paraná State in the layer $0-20 \mathrm{~cm}$ deep.

\begin{tabular}{|c|c|c|c|c|c|c|c|c|c|}
\hline \multirow{2}{*}{ Soil } & \multirow{2}{*}{$\mathrm{pH}$} & \multirow{2}{*}{$\begin{array}{c}\text { Organic } \\
\text { matter }\end{array}$} & \multirow{2}{*}{ Clay } & \multicolumn{4}{|c|}{ Exchangeable cations } & \multirow{2}{*}{ CEC } & \multirow{2}{*}{$\mathrm{V}$} \\
\hline & & & & $\mathrm{K}^{+}$ & $\mathrm{Ca}^{2+}$ & $\mathrm{Mg}^{2+}$ & $\mathrm{Al}^{3+}$ & & \\
\hline & & $\mathrm{g} \mathrm{dm}^{-3}$ & $\mathrm{~g} \mathrm{~kg}^{-1}$ & \multicolumn{4}{|c|}{---------- $\mathrm{mmol}_{\mathrm{c}} \mathrm{dm}^{-3}$} & & $\%$ \\
\hline LV1 & 4.6 & 13.2 & 900 & 3.8 & 31 & 18 & 5.5 & 149 & 35 \\
\hline LV2 & 3.8 & 12.4 & 785 & 1.8 & 26 & 6 & 7.5 & 141 & 25 \\
\hline LVA1 & 4.9 & 11.8 & 250 & 1.6 & 39 & 22 & 2.0 & 129 & 64 \\
\hline LVA2 & 4.2 & 17.1 & 315 & 1.6 & 30 & 10 & 4.5 & 131 & 31 \\
\hline NV1 & 5.2 & 19.0 & 550 & 3.0 & 56 & 19 & 1.5 & 157 & 49 \\
\hline NV2 & 3.9 & 24.3 & 780 & 2.1 & 23 & 6 & 11.0 & 161 & 19 \\
\hline PVA1 & 5.2 & 5.3 & 85 & 1.5 & 21 & 4 & 1.5 & 64 & 43 \\
\hline PVA2 & 3.7 & 16.8 & 700 & 3.4 & 61 & 17 & 33.5 & 166 & 49 \\
\hline $\mathrm{RR}$ & 5.1 & 9.1 & 635 & 3.7 & 59 & 23 & 1.5 & 153 & 56 \\
\hline $\mathrm{FX}$ & 3.8 & 18.1 & 615 & 1.9 & 12 & 4 & 12.0 & 142 & 12 \\
\hline GX & 3.6 & 12.0 & 450 & 1.2 & 44 & 14 & 35.0 & 175 & 34 \\
\hline CX & 5.2 & 9.4 & 235 & 2.6 & 28 & 12 & 1.0 & 99 & 42 \\
\hline
\end{tabular}

$\mathrm{pH}$ in $\mathrm{CaCl}_{2} 0.01 \mathrm{~mol} \mathrm{~L}^{-1}$, soil:solution ratio $(1: 2,5)$. Organic matter, Walkley - Black method. Clay content determined by the pipette method (Embrapa, 1997). K extract by Mehlich-1. Ca, Mg and Al extracted by $\mathrm{KCl}$ solution $1 \mathrm{~mol} \mathrm{~L}^{-1}$. CEC: cation exchange capacity. V: soil base saturation.

Source: Elaboration of the authors.

The greenhouse experiment consisted of a soybean crop [Glycine max L. (Merrill) cultivar CD 215]. The treatments, represented by 12 soil types, were arranged in a randomized block design with four replicates. Eight soybean seeds were sown per pot and, after thinning, two plants were left in each pot. Fertilization was performed with macro and micronutrients in solution four days after plant emergence, as recommended for soybean cultivation in a greenhouse as described by Novais, Neves and Barros (1991), with modification. The only exception was the amount of $\mathrm{P}$, which was omitted in the application of nutrients. The total quantities of fertilizer were: $\mathrm{N}-40 \mathrm{mg} \mathrm{dm}{ }^{-3}$ (ammonium sulfate), $\mathrm{K}-120 \mathrm{mg} \mathrm{dm}^{-3}$ (potassium chloride), $\mathrm{S}-15 \mathrm{mg} \mathrm{dm}^{-3}$ (calcium sulfate), $\mathrm{Cu}-5 \mathrm{mg} \mathrm{dm}^{-3}$ (copper sulfate), $\mathrm{Zn}-5 \mathrm{mg} \mathrm{dm}^{-3}$ (zinc sulfate), Mo - $1 \mathrm{mg} \mathrm{dm}^{-3}$ (ammonium molybdate) and $\mathrm{B}-2$ $\mathrm{mg} \mathrm{dm}{ }^{-3}$ (boric acid). At 15 and 30 days after plant emergence, the application of $40 \mathrm{mg} \mathrm{dm}^{-3} \mathrm{~N}$ as urea a solution was also performed. The soil water content was monitored daily and adjusted when necessary to keep it close to $80 \%$ field capacity.
The harvest of plants was performed 42 days after emergence. Shoots of plants were cut close to the soil surface, dried in a forced air circulation oven at $65 \pm 2{ }^{\circ} \mathrm{C}$ for $72 \mathrm{~h}$, weighed and ground in a Wiley type mill. The $\mathrm{P}$ content in the plant material was determined by nitric-perchloric digestion and the dosage of extracts was assessed using a colorimetric spectrophotometer according to Embrapa (1999). The amount of $P$ accumulated in plants was determined from the dry matter produced per pot and calculated as its content in dry matter.

Before sowing, soil samples were collected from the upper 0-20 cm using a hole-type auger $25 \mathrm{~mm}$ in diameter. After collection, samples were airdried, passed through a sieve of $2.0 \mathrm{~mm}$ mesh and stored. $\mathrm{P}$ contents available in soil were extracted by: i) Mehlich-1 ( $\mathrm{HCl} 0.05$ mol L-1 $+\mathrm{H}_{2} \mathrm{SO}_{4} 0.0125$ mol L-1) extracted from a soil:solution ratio of $1: 10$, with 5 min of stirring time in a horizontal shaker at 120 oscillations per minute and settling for $16 \mathrm{~h}$, according to the method described by Tedesco et al. (1995); ii) Mehlich-3 $\left(\mathrm{CH}_{3} \mathrm{COOH} 0.2 \mathrm{~mol} \mathrm{~L}^{-1}\right.$ $\mathrm{NH}_{4} \mathrm{NO}_{3}+0.25 \mathrm{~mol} \mathrm{~L}^{-1}+\mathrm{NH}_{4} \mathrm{~F} 0.015 \mathrm{~mol} \mathrm{~L}^{-1} \mathrm{HNO}_{3}$ 
$+0.013 \mathrm{~mol} \mathrm{~L}^{-1}+$ EDTA $0.001 \mathrm{~mol} \mathrm{~L}^{-1}$ ) extracted from a soil:solution ratio of $1: 10$, with $5 \mathrm{~min}$ of stirring time in a horizontal shaker at 220 oscillations per minute and settling for $16 \mathrm{~h}$ (TEDESCO et al., 1995) and iii) mixed ion exchange resin, extracted from a soil:solution ratio of 1:20, with $16 \mathrm{~h}$ of stirring time (RAIJ et al., 2001). In all extracts, $\mathrm{P}$ was determined by colorimetry at a wavelength of $725 \mathrm{~nm}$.

The $\mathrm{P}$ content extracted by Mehlich-1, Mehlich-3 and resin and the accumulated amounts in the shoots of soybean plants were subjected to analysis of variance (ANOVA), with the effect of contents deployed for each extractor determined by linear regression analysis. Correlation analyses were performed between the different extractors and between the contents extracted from soils and the amount accumulated in plants. The predictive capacity for assessing $\mathrm{P}$ availability by the different extractors was carried out mainly by the analyses of correlation coefficients.

\section{Results and Discussion}

Comparing the extractors, it was observed that the Mehlich-1 method extracted lower amounts of $\mathrm{P}$ compared to the resin, and the amount of phosphorus extracted by the resin method was lower than that extracted by the Mehlich-3 solution (Table 3). Overall, these results agree with the literature (BORTOLON; SCHLINDWEIN; GIANELLO, 2009; SILVA et al., 2008; SCHLINDWEIN; GIANELLO, 2008; BORTOLON; GIANELLO, 2008; ALCÂNTARA et al., 2008; RING et al., 2004; MALLARINO; ATIA, 2005; GARTLEY et al., 2002) and can be attributed to the different extraction mechanisms of these methods.

Table 3. Mean values, minimum and maximum for soil phosphorus contents extracted by different methods before soybean cultivation, phosphorus content and accumulation in the shoot and dry matter production $(n=48)$.

\begin{tabular}{|c|c|c|c|c|c|c|}
\hline \multirow{2}{*}{ Parameter } & \multicolumn{3}{|c|}{ Soil phosphorus } & \multicolumn{2}{|c|}{ Plant phosphorus } & \multirow{2}{*}{ Dry matter } \\
\hline & Mehlich-1 & Melhich-3 & Resin & Content & Accumulated & \\
\hline & \multicolumn{3}{|c|}{ 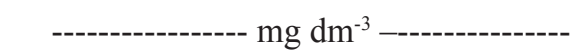 } & $\mathrm{g} \mathrm{kg}^{-1}$ & $\mathrm{mg} /$ pot & $\mathrm{g} /$ pot \\
\hline Minimum & 2.0 & 0.9 & 1.4 & 3.9 & 62.8 & 7.7 \\
\hline Maximum & 53.1 & 82.6 & 70.0 & 11.8 & 122.4 & 22.4 \\
\hline Mean & 16.4 & 23.2 & 21.8 & 6.5 & 90.0 & 14.7 \\
\hline Median & 12.3 & 19.2 & 15.9 & 6.0 & 89.6 & 14.5 \\
\hline
\end{tabular}

Source: Elaboration of the authors.

The Mehlich-1 solution extracts $\mathrm{P}$ by selective dissolution of the more labile fractions due to a reduction in $\mathrm{pH}$. In clay soils with high buffering capacity, as were most of soils analyzed in this study (Table 2), the settling time of 16 hours used in the extraction method (TEDESCO et al., 1995) can lead to the wastage of extraction capacity with the readsorption of already dissolved $\mathrm{P}$, resulting in lower $\mathrm{P}$ values recovered in clay soils compared to sandy soils (MOREIRA; MALAVOLTA, 2001;
SILVA; RAIJ, 1999). In turn, this effect is reduced with the resin method when extracting P from a soil solution by the ion exchange mechanism between bicarbonate adsorbed on the resin, which by the concentration gradient moves into the solution, and is replaced by phosphate at the adsorption sites on the resin to maintain chemical balance.

The higher P content extracted with Mehlich-3 is due in part to the extractor's chemical characteristics, which preferentially extracts $\mathrm{P}$ bound to $\mathrm{Fe}$ and $\mathrm{Al}$ 
(elements present in large quantities in soils) and, to a lesser extent, $\mathrm{P}$ bound to $\mathrm{Ca}$ (MOREIRA; MALAVOLTA, 2001; SILVA; RAIJ, 1999). The highest amounts of $\mathrm{P}$ extracted allow broader classes of fertility and reduce the error in fertilizer recommendations.

The correlation coefficients for the amounts of $\mathrm{P}$ extracted by these methods are shown in Figure 1. The $\mathrm{P}$ content extracted by the Mehlich-1 method correlated significantly with the concentrations extracted by Mehlich-3 and ion exchange resin. The correlation coefficients between the P contents extracted with Mehlich-1 and Mehlich-3 and resin were, respectively, 0.94 and 0.88 (Figures 1a and 1b), while the correlation between Mehlich-3 and resin was 0.93 (Figure 1c). This high degree of association and significance between extractors indicates that all the studied methods can be used to assess phosphorus availability to plants in the soils of Paraná state. However, due to the greater convenience of operation in routine laboratories, mainly due to the ease of obtaining clear extracts by decantation, thus eliminating the filtration of soils suspensions, and the low cost of analysis (ROSSI, FAGUNDES, 1998), Mehlich-1 is more suitable for the evaluation of available $\mathrm{P}$ in soil.

The relationship between the $\mathrm{P}$ content in soil extracted by different extractors and the amount of $\mathrm{P}$ accumulated in soybean plants is shown in
Figure 2. The correlation coefficients between the $\mathrm{P}$ contents extracted from soil and the amount of $\mathrm{P}$ accumulated in the plants were 0.86 for Mehlich-1, 0.90 for Mehlich-3 and 0.93 for ion exchange resin (Figures 2a, 2b and 2c).

All extractors were effective in estimating $\mathrm{P}$ availability to soybean plants in different soils of the State of Paraná with wide variation in chemical, physical and mineralogical properties. According to Alvarez Venegas (1996), an appropriate method to assess nutrient availability to plants should be effective for a broad range of soil types and different types of crops, which was observed in this study. These results agree with Kliemann and Santos (2005), who also verified the high efficiency of Mehlich-1, Mehlich-3 and resin in assessing $\mathrm{P}$ availability for millet plants in Cerrado soils. The correlation coefficients obtained between the extracted contents from soil and the amount accumulated in plants ranged from 0.87 to 0.90 with Mehlich-1, 0.91 to 0.96 with Mehlich-3 and from 0.82 to 0.91 with the ion exchange resin. The high efficiency of Mehlich-1, Mehlich-3 and resin in estimating $\mathrm{P}$ availability for the main crops grown in Brazil have been reported by Schlindwein, Bortolon and Gianello (2011), Bortolon et al. (2011), Bortolon, Gianello and Schlindwein (2009), Bortolon, Schlindwein and Gianello (2009), Bortolon and Gianello (2008) and Moreira and Malavolta (2001). 
Figure 1. Correlation between phosphorus contents extracted from soil by different methods in soil samples from Paraná collected before soybean cultivation. **: Significant at $1 \%$. $(\mathrm{n}=48)$.
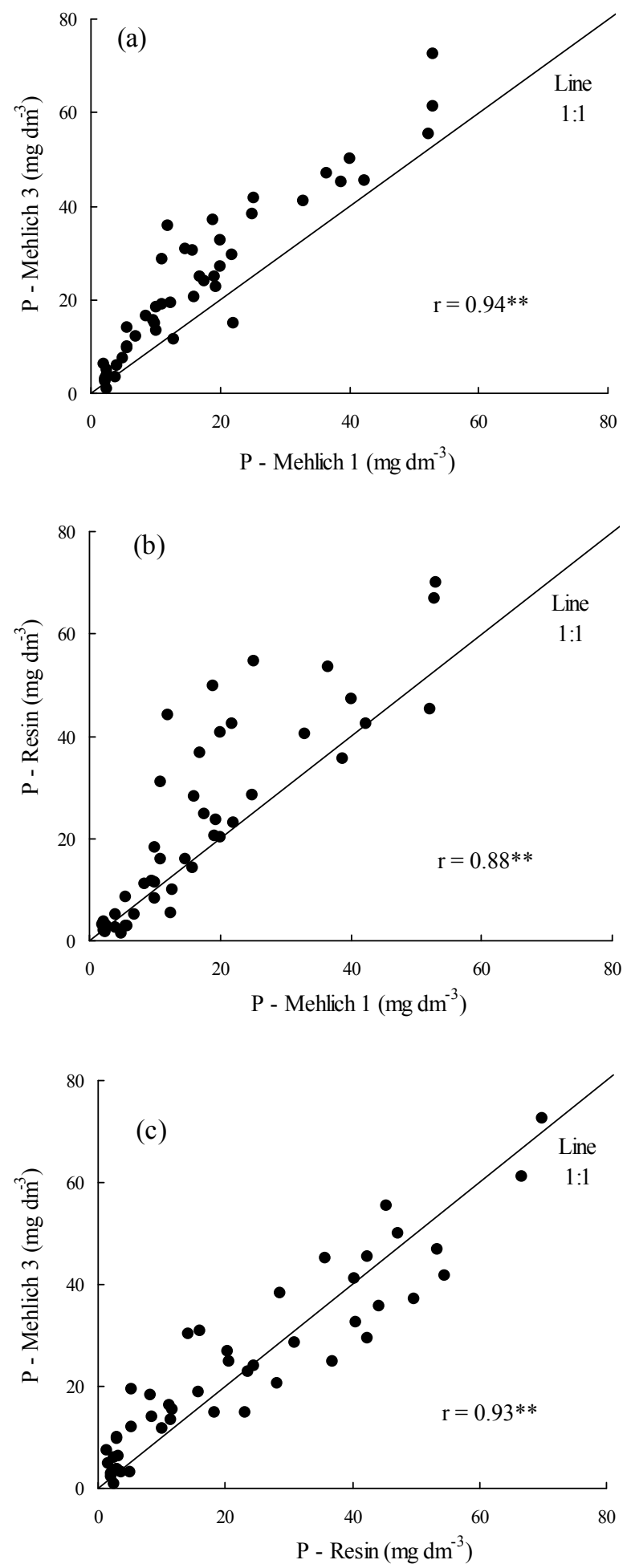

Source: Elaboration of the authors.
Figure 2. Relationship between phosphorus contents extracted from soil by Mehlich-1 (a) Mehlich-3 (b) and ion exchange resin (c) and the amount of phosphorus accumulated in soybean plants. **: Significant at $1 \%$. (n $=48)$.
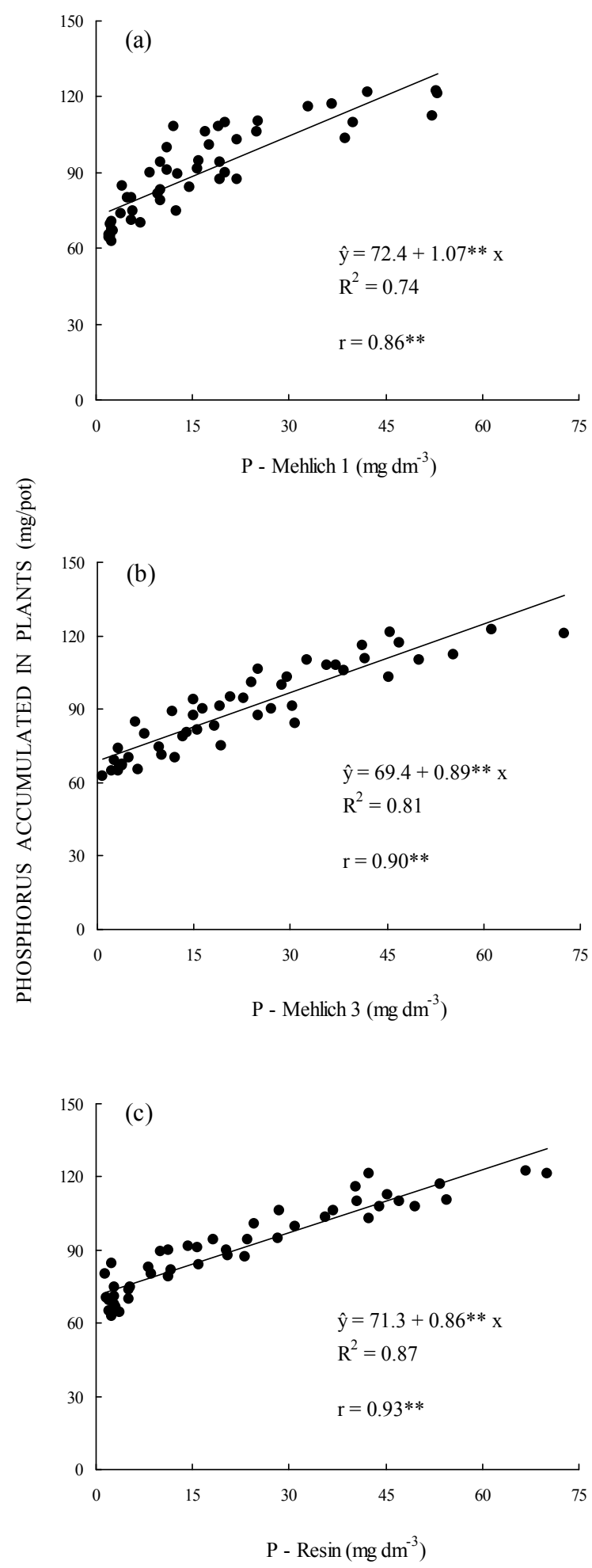

Source: Elaboration of the authors. 


\section{Conclusions}

Under natural fertility conditions and in soils that have received no application of poorly reactive rock phosphates, the Mehlich-1, Mehlich-3 and ion exchange resin methods showed similar efficiency in the evaluation of P availability to plants and can be used to quantify P contents in the soils of Paraná state.

\section{References}

ALCÂNTARA, F. A.; FURTINI NETO, A. E.; CURI, N.; RESENDE, A. V. Extraction methods for phosphorus and their relationship with soils phosphorus-buffer capacity estimated by the remaining-phosphorus methodology-a pot study with maize. Communications in Soil Science and Plant Analysis, New York, v. 39, n. 3-4, p. 603-615, 2008.

ALVAREZ VENEGAS, V. H. Correlação e calibração de métodos de análise de solos. In: ALVAREZ VENEGAS, V. H.; FONTES, L. E. F.; FONTES, M. P. F. (Ed.). $O$ solo nos grandes domínios morfoclimáticos do Brasil e o desenvolvimento sustentado. Viçosa: SBCS/UFV/DPS. 1996. p. 615-646.

BORTOLON, L.; GIANELLO, C. Interpretação de resultados analíticos de fósforo pelos extratores Mehlich-1 e Mehlich-3 em solos do Rio Grande do Sul. Revista Brasileira de Ciência do Solo, Viçosa, v. 32, p. 1369-1377, 2008. Especial.

BORTOLON, L.; SCHLINDWEIN, J. A.; GIANELLO, C. Métodos de extração de fósforo e potássio no solo sob sistema plantio direto. Ciência Rural, Santa Maria, v. 39, n. 8, p. 2400-2407, 2009.

BORTOLON, L.; GIANELLO, C.; SCHLINDWEIN, J. A. Avaliação da disponibilidade de fósforo no solo para o milho pelos métodos Mehlich-1 e Mehlich-3. Scientia Agraria, Curitiba, v. 10, n. 4, p. 305-312, 2009.

BORTOLON, L.; GIANELLO, C.; WELTER, S.; ALMEIDA, R. G. O.; GIASSON, E. Simultaneous extraction of phosphorus, potassium, calcium and magnesium from soils and potassium recommendations for crops in southern Brazil. Pedosphere, Beijing, v. 21, n. 3, p. 365-372, 2011.

EMPRESA BRASILEIRA DE PESQUISA AGROPECUÁRIA - EMBRAPA. Centro Nacional de Pesquisa de Solos (Rio de Janeiro, RJ). Manual de métodos de análise de solo. 2. ed. Rio de Janeiro: Embrapa Solos, 1997, 212 p.
Manual de análises químicas de solos, plantas e fertilizantes. Brasília: Embrapa Comunicação para Transferência de Tecnologia, 1999, 370 p.

Sistema brasileiro de classificação de solos. 2. ed. Rio de Janeiro: Embrapa Solos, 2006. 306 p.

FIXEN, P. E.; GROVE, J. H. Testing soils for phosphorus. In: WESTERMAN, R. L. (Ed.). Soil testing and plant analysis. Madison: Soil Science Society of America, 1990. p. 141-180.

GARTLEY, K. L.; SIMS, J. T.; OLSEN, C. T.; CHU, P. Comparison of soil test extractants used in Mid-Atlantic United States. Communications in Soil Science and Plant Analysis, New York, v. 33, n. 5-6, p. 873-895, 2002.

GONZÁlEZ, J. V.; CAJUSTE, L. J.; SANTOS, A. T.; REYES, F. G. Correlación y calibración de soluciones extractantes del fósforo aprovechable em Andisoles de la Sierra Tarasca. Terra, Chapingo, v. 17, n. 4, p. 287-291, 2000.

MALLARINO, A. P.; ATIA, A. M. Correlation of a resin membrane soil phosphorus test with corn yield and routine soil tests. Soil Science Society of America Journal, Madison, v. 69, n. 1, p. 266-272, 2005.

MOREIRA, A.; MALAVOLTA, E.; VIRGENS FILHO, A. C.; SILVEIRA, R. L. V. A.; ABREU, J. B. R. Avaliação da disponibilidade do fósforo no solo por métodos isotópico, químicos e biológico. Scientia Agricola, Piracicaba, v. 54, n. 1-2, p. 78-84, 1997.

MOREIRA, A.; MALAVOLTA, E. Fontes, doses e extratores de fósforo em alfafa e centrosema. Pesquisa Agropecuária Brasileira, Brasília, v. 36, n. 12, p. 15191527, 2001.

NOVAIS, R. F.; NEVES, J. C. L.; BARROS, N. F. Ensaio em ambiente controlado. In: OLIVEIRA, A. J. de; GARRIDO, W. E.; ARAÚJO, J. D. de; LOURENÇO, S. (Coord.). Métodos de pesquisa em fertilidade do solo. Brasília: EMBRAPA-SEA, 1991. p. 189-253. (Documentos, 3).

OLIVEIRA, F. H. T.; NOVAIS, R. F.; SMYTH, T. J.; NEVES, J. C. L. Comparisons of phosphorus availability between anion exchange resin and Mehlich-1 extractions among Oxisols with different capacity factors. Communications in Soil Science and Plant Analysis, New York, v. 31, n. 5-6, p. 615-630, 2000.

RAIJ, B, van; ANDRADE, J. C.; CANTARELLA, H.; QUAGGIO, J. A. Análise química para avaliação da fertilidade de solos tropicais. Campinas: Instituto Agronômico, 2001. 285 p.

RAIJ, B. van; CANTARELLA, H.; QUAGGIO, J. A.; FURLANI, A. M. C. Recomendações de adubação e 
calagem para o Estado de São Paulo. 2. ed. Campinas: Instituto Agronômico, 1997. 285 p. (Boletim técnico, 100).

RAIJ, B. van; FEITOSA, C. T.; SILVA, N. M. Comparação de quatro extratores de fósforo nos solos. Bragantia, Campinas, v. 43, n. 1, p. 17-29, 1984.

RING, R. A.; WARMAN, P. R.; STRATTON, G. W.; EATON, L. J. Determining available soil phosphorus in Nova Scotia blueberry soils. Communications in Soil Science and Plant Analisys, New York, v. 35, n. 17-18, p. 2449-2463, 2004.

ROSSI, C.; FAGUNDES, J. L. Determinação do teor de fósforo em solos por diferentes extratores. Revista de Agricultura, Piracicaba, v. 73, n. 2, p. 215-227, 1998.

SANTOS, E. A.; KLIEMANN, H. J. Disponibilidade de fósforo de fosfatos naturais em solos de Cerrado e sua avaliação por extratores químicos. Pesquisa Agropecuária Tropical, Goiânia, v. 35, n. 3, p. 139-146, 2005.

SCHLINDWEIN, J.A.; BORTOLON, L.; GIANELLO, C. Soil phosphorus available for crops and grasses extracted with three soil-test methods in southern Brazilian soils amended with phosphate rock. Communications in Soil Science and Plant Analysis, New York, v. 42, n. 3, p. 283292, 2011.

SCHLINDWEIN, J. A.; GIANELLO, C. Calibração de métodos de determinação de fósforo em solos cultivados sob sistema plantio direto. Revista Brasileira de Ciência do Solo, Viçosa, v. 32, n. 5, p. 2037-2049, 2008.
SILVA, F. C.; RAIJ, B. van. Disponibilidade de fósforo em solos avaliada por diferentes extratores. Pesquisa Agropecuária Brasileira, Brasília, v. 34, n. 2, p. 267-288, 1999.

SILVA, L. S.; RANNO, S. K.; RHODEN, A. C.; SANTOS, D. R.; GRAUPE, F. A. Avaliação de métodos para estimativa da disponibilidade de fósforo para arroz em solos de várzea do Rio Grande do Sul. Revista Brasileira de Ciência do Solo, Viçosa, v. 32, n. 1, p. 207216, 2008.

SILVA, W. M.; FABRÍCIO, A. C.; MARCHETTI, M. E.; KURIHARA, C. H.; MAEDA, S.; HERNANI, L. C. Eficiência de extratores de fósforo em dois Latossolos do Mato Grosso do Sul. Pesquisa Agropecuária Brasileira, Brasília, v. 34, n. 12, p. 2277-2285, 1999.

TEDESCO, M. J.; GIANELlO, C.; BISSANI, C. A.; BOHNEN, H.; VOLKWEISS, S. J. Análises de solos, plantas e outros materiais. 2. ed. Porto Alegre: Universidade Federal do Rio Grande do Sul, 1995. 174 p. (Boletim técnico, 5).

WANG, J. J.; HARRELL, D. L.; HENDERSON, R. E.; BELL, P. F. Comparison of soil-test extractants for phosphorus, potassium, calcium, magnesium, sodium, zinc, copper, manganese, and iron in Louisiana soils. Communications in Soil Science and Plant Analysis, New York, v. 35, n. 1-2, p. 145-160, 2004. 
